\title{
Long-term Changes in the Ichthyofauna of Latvia's Inland Waters
}

\author{
Eriks Aleksejevs ${ }^{1}$, Janis Birzaks ${ }^{2},{ }^{1-2}$ Institute of Food Safety, Animal Health and Environment - "BIOR" Fish \\ Resources Research Department
}

\begin{abstract}
Changes in the ichthyofauna of Latvia's inland waters and their causes have been analyzed. Information about the distribution and occurrence of fish, obtained from various sources of literature, official reports, "BIOR" data bases on fishery statistics, as well as field research done from 1990 to 2010 , has been collected and compared. Anthropogenic activity in the 20th century, such as rivers blocking by dams and fish introduction and acclimatization, has affected ichthyofauna more significantly.
\end{abstract}

Keywords - Latvia, inland fish, changes of ichthyofauna, inland waters

\section{I.INTRODUCTION}

The oldest data about fish which could be found in the inland waters of the current territory of Latvia relates to human settlements from 8-1 millennia BC and in the $11^{\text {th }}-17^{\text {th }}$ centuries [12]. The first publications mentioning the occurrence of fish in the Eastern Baltic region, as well as the occurrence of fish in individual waterbodies in the current territory of Latvia, were published in the $19^{\text {th }}$ century and the beginning of the $20^{\text {th }}$ century $[2,10]$.

Broader surveys on the species of fish occurring in Latvia, including in inland waters, were published from 1935 to 1998 $[7,8,9,13,19]$. During this period, a range of articles were published about rare species of fish [4], and research on economically significant species and the occurrence of species in separate lakes and rivers, as well as fisheries and fish fauna related research in separate waterbodies, was conducted.

From 1990 to 2010, wider research was undertaken with the goal of evaluating the composition of fish communities, and the occurrence of species and their distribution in Latvia's rivers, lakes and artificial reservoirs. The results of this research have not previously been published and long-term changes in fish occurrence and distribution have not been analyzed.

The potential effect of climate change on fish distribution is the topic of wide discussion; the possible scenarios predict changes in the structure of the fish community with warm water fish species replacing cold water species. Climate changes in the Baltic Sea basin have expressed themselves as climate periods, which have replaced each other, starting from the Sub-Arctic Boreal period 9000 years ago until the SubAtlantic nowadays. Extremes of climate which were registered in the Chronicles starting from the $13^{\text {th }}$ century are known about, but regular observations have been made since the $19^{\text {th }}$ century. The latter provide evidence of such significant ecological parameter changes for fish as: changes in river discharge, in the distribution of precipitation and in the biota as a whole.

The most important regulating factor in the distribution and occurrence of fish is the concentration of oxygen in the water. In natural conditions, in the temperate climate zone, where Latvia is located, the wide-scale deaths of fish in lakes can be observed in winter quite often as a result of oxygen deficiency. In certain types of lakes, as well as in the natural development and evolution processes of lakes, fish winter kills determine the composition of fish fauna in the short, as well as long term.

Changes caused by anthropogenic influences in the distribution and occurrence of fish took place mainly in the last 50-100 year period. The distribution and occurrence of diadromous species caused by a reduction in the number of rivers available to them have been affected by anthropogenic obstacles in rivers. At the same time, hydromorphological transformation has taken place and water quality has deteriorated as a result of pollution and eutrophication.

Beginning with the end of the $19^{\text {th }}$ century, the introduction of foreign species has taken place, as well as the transportation of local fish species and their release to supplement fish resources, and unsanctioned and casual distribution of foreign and local fish species [15].

The aim of this work is, by collating the information at our disposal, to make an assessment of what kinds of changes have taken place in Latvia's fish fauna within the $20^{\text {th }}$ and $21^{\text {st }}$ century through natural and anthropogenic factors. Bearing in mind that research conducted on the distribution and occurrence of fish in Latvia was very limited until the 1990s, one of the aims of the article is to collate and publish data about the current actual distribution and occurrence of fish species.

\section{MATERIALS AND METHODS}

In addition to the published information sources, the following unpublished data have been used and analyzed in the article:

- the former Baltic Fish Conservation and Reproduction Administration archive materials and official reports for the period from 1946 to 1990 ;

- the "BIOR" Institute's materials from 1953 to 2009 ;

- commercial fishing statistical data on 759 lakes, 22 rivers and 46 reservoirs from 1929 to 2010 ; 
- fishermen's catch results for 112 lakes, 3 rivers and 10 reservoirs from 1973 to 2009 ;

- data on the release of fish into 400 lakes, 55 rivers and 27 reservoirs from 1885, which have been collected from publications, archives and information provided by hatcheries.

In total, data on 1097 lakes, 435 rivers and 227 reservoirs in which at least one species of fish is mentioned as occurring, are available in publications, official reports and surveys.

Wider scale research with the goal of evaluating the structure of the fish community and the distribution and occurrence of species has been taking place since 1990 at the Latvian Fisheries Research Institute (currently the "BIOR" Fish Resources Research Department). Over this time, 358 lakes, 313 rivers and 43 reservoirs have been covered. In research fishing nets with varying mesh sizes $(8-70 \mathrm{~mm})$, a beach seine or drag-net and electro-fishing equipment have been used. In individual cases, fish caught in commercial fishing have also been analyzed. In total, 45 species of fish, of those 6 introduced, as well as 3 species of lamprey, have been detected. The scientific names of the species used in the article are according to Kottelat and Freyhof [3].

\section{RESULTS AND DISCUSSION}

The oldest evidence about fish which could be encountered in the inland waters of the current territory of Latvia, which date from 8-1 millennia $\mathrm{BC}$ and in the $11^{\text {th }}-17^{\text {th }}$ centuries, have been provided by archaeological excavations. The bones of 21 species of freshwater and migratory fish have been found in ancient settlement sites, hill forts and in the Riga City archaeological layers. These were species which our ancestors used for food [12].

In the $18^{\text {th }}$ and $19^{\text {th }}$ century publications about the fish of the Eastern Baltic region [2, 10], 3 lamprey and 42 fish species have been mentioned as occurring in the inland waters of the current territory of Latvia, and the individual sites where they were found, have been indicated.

The first reports about Latvia's ichthyofauna were published in the 1930s. The following 3 lamprey and 42 fish species were ascribed to Latvia's inland waters: the river lamprey Lampetra fluviatilis, brook lamprey Lampetra planeri, sea lamprey Petromyzon marinus, Atlantic sturgeon Acipenser sturio, eel Anguilla anguilla, allis shad Alosa alosa, twaite shad Alosa fallax, bitterling Rhodeus amarus, gudgeon Gobio gobio, crucian carp Carassius carassius, carp Cyprinus carpio, bream Abramis brama, schneider Alburnoides bipunctatus, bleak Alburnus alburnus, asp Aspius aspius, blue bream Ballerus ballerus, silver bream Blicca bjoerkna, sun bleak Leucaspius delineatus, ide Leuciscus idus, dace Leuciscus leuciscus, ziege Pelecus cultratus, minnow Phoxinus phoxinus, roach Rutilus rutilus, rudd Scardinius erythropthalmus, chub Squalius cephalus, vimba Vimba vimba, tench Tinca tinca, spined loach Cobitis taenia, weather loach Misgurnus fossilis, stone loach Barbatula barbatula, catfish Silurus glanis, pike Esox lucius, smelt Osmerus eperlanus, vendace Coregonus albula, whitefish Coregonus lavaretus, Atlantic salmon Salmo salar, trout Salmo trutta of two forms (migratory and sedentary), grayling Thymallus thymallus, burbot Lota lota, threespine stickleback Gasterosteus aculeatus, ninespine stickleback Pungitius pungitius, bullhead Cottus gobio, ruffe Gymnocephalus cernua, perch Perca fluviatilis and pike perch Sander lucioperca $[7,11]$.

Reports on Latvia's ichthyofauna released in the 1940s and 1950s [9, 19] are generally similar, with 3 lamprey and 49 fish species mentioned in them. During this period, the barbel Barbus barbus and Alpine sculpin Cottus poecilopus were ascribed as natural and occurring species in Latvia's inland waters, but the sterlet Acipenser ruthenus, Prussian carp Carassius gibelio, rainbow trout Oncorhynchus mykiss, arctic chaar Salvelinus alpinus and brook trout Salvelinus fontinalis were ascribed as introduced species.

In the latest publication of Latvia's ichthyofauna [8], 3 lamprey and 62 fish species have been included, which various authors have ascribed to Latvia's inland waters, and that have been caught in commercial fishing or brought in and introduced in natural waters. But since this work was published, a large amount of significant new and previously unpublished information about fish distribution and occurrence in Latvia's inland waters has been gathered. This data provides the opportunity to evaluate and analyze the kinds of changes that have occurred to Latvia's ichthyofauna.

\section{A. Effect of natural factors on Latvia's inland water ichthyofauna}

The detailed effect of natural factors on the distribution and occurrence of fish is not known, but in the long term it has obviously been linked to climate change.

Judging from findings in archaeological excavations, warmwater fish species like the catfish, pike perch and the asp were more widely distributed in ancient times than in the $19^{\text {th }}$ $20^{\text {th }}$ centuries, but nowadays their distribution is once again increasing.

Pikeperch bones have been found in excavations in the whole territory of Latvia in 12 or $75 \%$ of the 16 settlements and archeological layers inspected [12]. This provides evidence that in the time period from 6 millennia $\mathrm{BC}$ until the $17^{\text {th }}$ century the pikeperch was comparatively widely distributed and often found.

Whereas, in the 1930s the pikeperch was still considered to be a rare species of fish in Latvia's waters [7]. This is also confirmed by the lake inventory data done in the 1950s, where it was found that the pikeperch only occurred in 27 lakes or $5 \%$ of the 549 lakes surveyed [17].

Judging from data from the Stone Age (6 - 8 millennia BC) gained in archaeological excavations, asp and catfish also lived in Burtnieku Lake [12]. In the 1950s these species of fish could no longer be found in the lake [17]. They are not mentioned in commercial fishing statistics in the period from 1928 to 2010. Neither asp, nor catfish were found in lake surveys undertaken 4 times from 1996 to 2001.

From the 1960s until today, the Daugava with its largest tributaries and the lakes connected to the river around Riga 
were mentioned as the area of distribution of catfish in various sources of literature $[8,13]$. It is also mentioned that catfish could once be found in Puzes Lake [2], but it had later obviously disappeared.

Since the 1950s, catfish has also been found in the Sila Lake connected to the Daugava, where it has been regularly fished in the period from 1994 to 2009. Catfish was also caught in the lake survey period in 2006, confirming the existence of its population in this lake. From the survey data, catfish can also be found in Riču Lake which is directly connected to Sila Lake. In the last seven years the catfish has been mentioned in fishing haul statistics in two additional inland lakes - Dagda and Smilǵginu lakes which are not directly connected to the Daugava.

Whereas, the stenothermic (cold water) species, lake smelt and vendace have had a distinct tendency to reduce in both population, as well as in number, beginning with the $20^{\text {th }}$ century [2].

In the 1930s, vendace and lake smelt, together or individually, could be encountered in about 30 lakes in Latgale, as well as in Alūksnes Lake, Limbažu Lielezers and Puzes, Sventes and Usmas lakes [7]. From the inventory data undertaken in the 1950s on 549 Latvian lakes, obtained by collating information with varying levels of credibility, vendace could be encountered in 39 lakes, but lake smelt in 18 lakes [17]. In the research work conducted over the same period, vendace was found in only 8 lakes.

Nowadays, vendace has been detected in 11 lakes, but according to the survey data, it could be encountered in 5 more lakes. In turn, lake smelt have been established in 6 lakes, but could be encountered in 5 more lakes, according to the survey datam with varying levels of credibility.

Despite the lack of accurate information on the occurrence of vendace and lake smelt at the commencement of the previous century, their number has obviously decreased as a result of climate change, biogenic pollution and lake eutrophication. Thus, although vendace were found in three lakes in the last century, they were not found during the research fishing, were not mentioned in commercial fishing statistics and were not found in the survey data since at least 1982.

In temperate zone lakes, large-scale fish deaths are characteristic of winter, due to conditions of oxygen deficiency. This is dependent on many factors, but lake morphology is very significant. In shallow and closed (without runoff) lakes, this phenomenon can be observed more often. In Latvia, fish suffocation has been observed in more than 238 lakes, and it occurs regularly in 26 of them, but in 59 lakes fish suffocation has been observed at least five times in the past century. Fish suffocation is a significant regulating factor of the ichthyofauna structure. In Latvia's conditions, as a result of fish suffocation, the disappearance of such species of fish as bream and pike perch, have been observed. For example, a comparatively large population of bream existed in Lielauces Lake until 1996. After the large-scale deaths of fish in the winter of $1995 / 1996$, this population completely disappeared and did not regenerate until 2004. However, in
Engures Lake, where large-scale deaths of fish occur regularly, the self-regenerating bream population obviously does not exist. A small number of bream migrate to Engures Lake from the coast of the Gulf of Riga. Thus, in 11 research fishing events done from 1992 to 2010, the number of bream has been below $1 \%$ of the total number of fish caught, or they were not caught at all.

In lakes, which are connected to other waterbodies, fish winterkills are less intensive; fish can migrate to adjacent bodies of water, as well as find places with a higher level of oxygen in mouths of rivers and streams. In closed lakes, fish suffocation can cause long-term changes in ichthyofauna, which manifests itself as a reduction in the number of fish species occurring in the lake where only 2-3 of the most tolerant species survive. However, it is not usually the case that all of the fish in a lake or all of the individuals of a species die as a result of fish suffocation. That is why the structure of the ichthyofauna and fish resources in these lakes renews itself within a few years after separate winterkill.

\section{B. Anthropogenic influence}

Anthropogenic activity, which directly influences the structure of the fish community, is diverse, but it can, in fact, be reduced to a few main effects, like the development of barriers in fish migration paths, transformation of habitats and a reduction in water quality.

Anthropogenic activity has had the most effect on migratory or diadromous fish. Their distribution, alongside with their occurrence and number, is dependent on opportunities for their migration along rivers to reach their spawning (anadromous species) or living and feeding (catadromous species) sites. Nowadays more than 700 artificial barriers have been counted in Latvia's waterways, which makes $60 \%$ of Latvia's territory inaccessible to migratory fish. The majority of them are watermill dams, and small HPS (hydro power stations) have been built on many of them in the period since 1990. In the period from 1939 - 1974, three hydro-electric station cascades were created on the Latvia's largest river, the Daugava. As a result of this, the number of rivers accessible to such migratory species of fish as salmon, sea trout, vimba, river lamprey and eel has been significantly reduced. The greatest part of this river's basin $\left(24,700 \mathrm{~km}^{2}\right.$ in Latvia's territory) and about 40 of its tributaries became inaccessible to migratory fish (diadromous) species. In accordance with data from the literature, up until the Daugava was dammed, these species of fish reached the territories of Belorus and Russia, which are located more than $500 \mathrm{~km}$ along the river away from the Gulf of Riga. It should be noted that vimba has partly adapted to the new situation, creating a landlocked population in the Plavinas Reservoir in the middle section of the river.

Commercial fishing data clearly show a reduction in the catches of migratory fish in Latvia, mainly in the Gulf of Riga and the rivers flowing into it, starting from 1975. The fishing haul of salmon and river lamprey has particularly declined (Figure 1). They also have not regenerated, despite regular restocking of their fingerlings and larvae in rivers. 


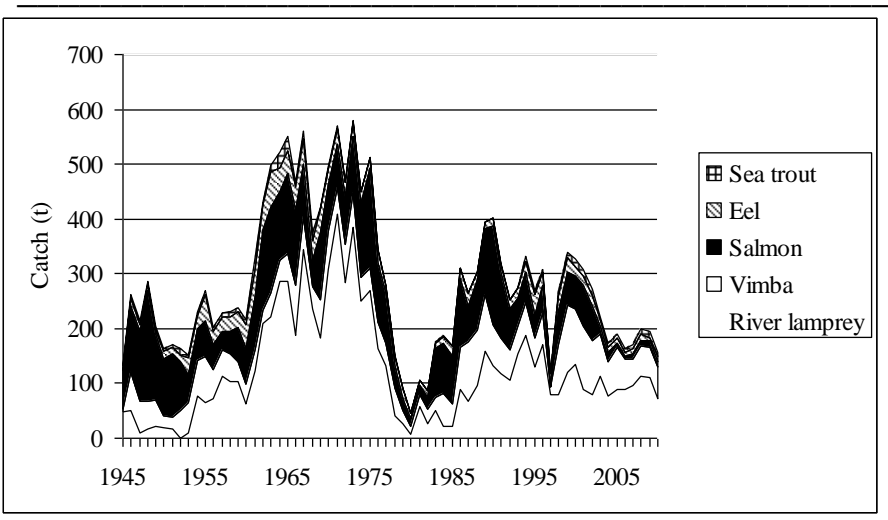

Fig. 1. Catches of migratory fish in Latvian coastal waters and rivers.

As opposed to the previously mentioned species of fish, smelt and three spined stickleback spawn in the lower reaches of rivers and their spawning places have not been destroyed as a result of the HPS construction. But the catches of these species decreased many times in the 1980s and have remained at a low level even now or have been completely discontinued, due to the shortage of resources (Figure 2).

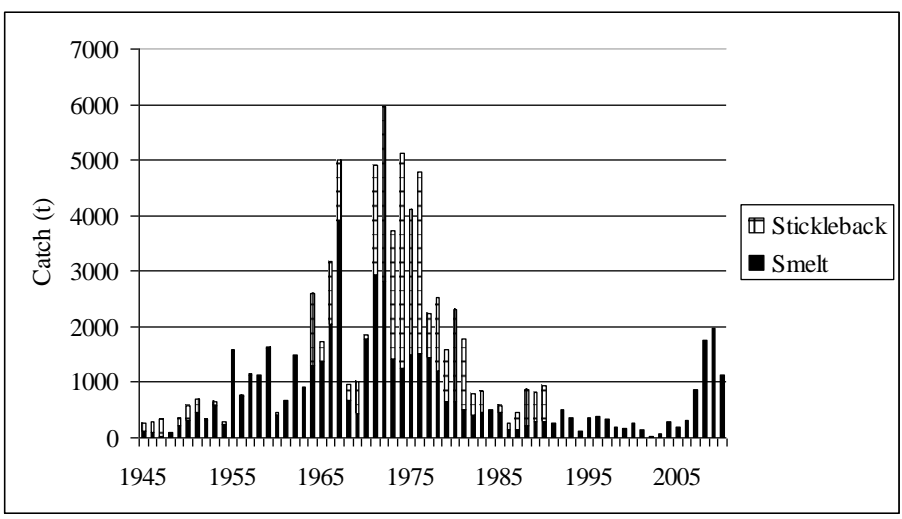

Fig. 2. Catches of three spined stickleback and smelt in the Gulf of Riga, coastal waters and rivers.

It is thought that the rapid reduction in the number of migratory fish in the 1970s-1980s was caused by a number of factors, in addition to the previously mentioned damming of the lower reaches of the Daugava, being river pollution and eutrophication and the morphological transformation of rivers. Unfortunately, it has not been possible to express the influence of these factors over time quantitatively. But, for example, information, which has been collated in River Basin Districts Management Plans, provides evidence that the majority of Latvia's surface water bodies are not of a good ecological quality. It should be noted that the reduction in the number of other species of fish in the Gulf of Riga was obviously also caused by the expansion of cod at the end of the 1970s and beginning of the 1980s. Still, the number of this species in the Gulf of Riga since 1986 has been at a very low level, and its fishing haul is almost zero. However, the number of migratory fish (anadromous) has not regenerated to the levels of the 1960s-1970s.
Eel is the only catadromous species of fish in the Baltic Sea basin. Eel is an ecologically flexible species and can be encountered in the sea and coastal waters, as well as in inland waters. Its distribution in Latvia nowadays has been determined by two processes.

On the one hand, starting from the 1940s until the 1980s, the release of glass eel and eel fingerlings was undertaken in all of the largest river basins, and about 55 lakes in total. The number of water bodies where this species could be encountered increased accordingly. Data from surveys done after the 1950s show that eel could be found in 150 lakes, but occurred frequently in only 12 of them [17]. From 1946 to 1992 it was registered in commercial fishing in 98 lakes and in all of the largest rivers (in the Daugava, Salaca, Gauja, Venta) and the reservoirs developed on them. Eel was registered in 14 lakes in the catches of commercial fishermen. It should be noted, that out of all of the abovementioned water bodies, natural migration of eel was possible in only 10 lakes, and, as to the others, eel was caught as a result of its artificial release and distribution. After 1990, eel was mentioned in the fishing haul statistics in 16 lakes, but only four of these water bodies are freely accessible to natural migration of eel, and in the others eels which were released in the 1960s-1990s were caught.

On the other hand, the natural distribution area of eel, just like for other species of migratory fish, has been reduced as a result of anthropogenic barriers.

Its catches in coastal waters were relatively stable until the 1970s, but then it began decreasing rapidly, like in other European countries. However, at the same time, the fishing haul of this species in inland waters grew, due to the intensive introduction of glass eel into the lakes in the Eastern part of Latvia.

Historically, eel was the most widespread species of migratory fish in Europe. Currently, its position has been recognized as being critical, and a range of normative acts have been adopted for its restoration, such as the Regulation EC 1100/2007. It is considered that the main factors which determine the condition of eel stocks nowadays are its fishing, blocking of migratory paths, deaths in HPS turbines, water pollution and diseases and parasites.

Changes in ichthyofauna to a large degree have also been determined by attempts to introduce and acclimatize new species. From 1885 until nowadays, at least 23 species of fish have been released in Latvia's inland waters. Work on the introduction and acclimatization of fish in Latvia's territory was commenced at least from 1885 [20]. To this day 23 species of fish have been released in Latvian waters: sterlet Acipenser ruthenus, Siberian sturgeon Acipenser baerii, Russian sturgeon Acipenser gueldenstaedtii, beluga Huso huso, Prussian carp Carassius gibelio, carp, silver carp Hupophthalmichthys molitrix, bighed carp Hupophthalmichthys nobilis, grass carp Ctenopharyngodon idella, black carp Mylopharyngodon piceus, Baikal omul Coregonus migratorius, muksun Coregonus muksun, broad whitefish Coregonus nasus, peled Coregonus peled, inconnu Stenodus nelma, pink salmon Oncorhynchus gorbuscha, chum 
salmon Oncorhynchus keta, coho salmon Oncorhynchus kisutch and rainbow trout Oncorhynchus mykiss, Arctic charr Salvelinus alpinus, brook charr Salvelinus fontinalis, striped bass Morone saxatilis, as well as the unsanctioned - Amur sleeper Percottus glenii $[1,8]$.

The release of local species in their natural waters is also being undertaken, alongside the introduction of alien species of fish in Latvian waters. The goal is to supplement the resources of fish for the needs of fishing. The acclimatization or re-acclimatization of local species of fish is also being done, i.e. distribution in the waters, where at the time of release these species had not occurred. Overall, the effect of the release of fish has affected a significant portion of Latvia's inland waters (Table 1).

TABLE 1

FISH INTRODUCTION AND RELEASE IN LATVIA'S INLAND WATERS

\begin{tabular}{|l|l|l|l|}
\hline $\begin{array}{l}\text { Water } \\
\text { body }\end{array}$ & $\begin{array}{l}\text { Introduction } \\
\text { of alien } \\
\text { species }\end{array}$ & $\begin{array}{l}\text { Release } \\
\text { of local } \\
\text { species }\end{array}$ & $\begin{array}{l}\text { Total number of water } \\
\text { bodies where fish have been } \\
\text { released }\end{array}$ \\
\hline Rivers & 10 & 72 & 72 \\
\hline Lakes & 246 & 299 & 405 \\
\hline Reservoirs & 30 & 28 & 39 \\
\hline
\end{tabular}

The majority of the species of fish introduced into Latvia's inland waters is not encountered nowadays, or can be encountered for only a limited period after their release, or is related to individuals caught after escaping from fish hatcheries or fish ponds. Of the alien species, self-sustaining populations have only developed for Prussian carp and Amur sleeper [8].

Prussian carp was introduced into Latvia in 1948 [1] and by 2010 had been released in more than 210 lakes. From various information sources, by 2010 Prussian carp could be ascribed to 299 lakes, 30 reservoirs and 25 rivers. In Latvian conditions, Prussian carp have also acclimatized to some natural waterbodies. Self-sustaining populations with a normal age structure can usually be found in lakes with a small number of fish species, where crucian carp, tench and sun bleak can also be encountered, in addition to Prussian carp, but usually there are no predator species pike and perch. Coastal lakes which are connected to the Gulf of Riga coast are an obvious exception. Correspondingly, Prussian carps of various ages $(0-10$ years $)$ have established themselves in Ķī̌sezers. In the last 15 - 20 years, a natural increase in the number of Prussian carp has been observed. For example, in coastal fishing, their fishing haul has increased from just kilograms in 1992 to $5.1 \mathrm{t}$ in 2010. A similar situation also exists in Estonian coastal waters.

Amur sleeper is the only known species of fish, which has been illegally introduced into Latvia's natural water bodies and which has acclimatized relatively successfully. It was first found during test-fishing in 1996 in the Lielais Trijkārtu Lake. From various information sources, Amur sleeper occurs in more than 23 lakes and 4 rivers, as well as in 14 artificial reservoirs. The number of waterbodies inhabited by Amur sleeper is obviously significantly higher, as ichtyological research is done very rarely in the water bodies which regularly dry out, to which it is most suited. Amur sleeper can be found in the former Bauska, Cēsis, Krāslava, Ludza, Ogre, Preil̦i, Rēzekne, Rīga, Tukums and Valmiera district territories. Up to now, it has not been possible to find information on its occurrence in Kurzeme (the western part of Latvia).

Carp can be considered to be the first species of fish introduced in Latvian waters. It had already been bred since the $13^{\text {th }}$ century in ponds created next to monasteries [1]. Information about their release in separate water bodies can be found only from the 1920s. By 2010, carp had been released in more than 226 lakes and 21 reservoirs. Carp also enter natural waters when fish ponds overflow, as well as through migration between connected water bodies. From various sources of information, carp have been ascribed to 361 lakes, 61 reservoirs and 36 rivers up to 2010. Carp spawning has been observed in a number of water bodies, but its effectiveness, excluding artificial ponds, is not known. In research on natural water bodies, individuals of only one age group are usually caught. This shows that the regular and effective regeneration of the carp population in natural waters in Latvia does not take place. Obviously, the place of carp in Latvia's ichthyofauna is maintained by carps which have escaped from fish hatcheries or those released in natural waters.

The artificial propagation of pike perch in Latvia's inland waters was commenced from at least 1904 and has continued up until today, with the increasing intensity [8]. Up to 2010, pike perch was released in more than 125 lakes, 13 reservoirs and 4 rivers. The number of waterbodies in which pike perch have appeared is even greater, as not all of its releases have been registered. Many lakes are mutually interconnected with waterways along which pike perch migration is possible. As a result, pike perch can be encountered nowadays in a total of 188 lakes, 20 reservoirs and 29 waterways. It should be noted that, as a result of the introduction of pike perch in waters in which it has not previously lived, self-sustainable populations have not always developed.

The results of field research, as well as data from commercial fishing statistics, allow us to make estimations about the actual occurrence of the pike perch currently. Of the 297 lakes inspected since 1990, pike perch have been found in 59 or in $20 \%$ of the total number. Over this time, pike perch was also regularly caught by commercial fishing in 10 other lakes as well. In addition to these 69 lakes, pike perch can also be found in the Daugava, its reservoirs and the largest tributaries, in the Gauja, Lielupe, Salaca and Venta, as well as the Pakul,u Reservoir on the Ciecere River.

Alonside with the increase in the number of water bodies inhabited by pike perch, caused by their artificial breeding, significant changes in the size of their population in separate lakes can also be observed. Thus, the commercial catches of pike perch were $1-7 \mathrm{~kg}$ per year in Burtnieku Lake in the 1930 s. In the 1950 s and 1960 s the catch periodically was from $12 \mathrm{~kg}$ to $258 \mathrm{~kg}$ per year, but in the last 5 years the average catch has been 9,757 kg per year. Whereas, in Lubāna Lake, from the 1950 s to the 1980 s pike perch practically was not mentioned in the commercial fishing statistics, but from 1990 
it has been caught regularly and in the last five years the average catch has been $10,515 \mathrm{~kg}$ per year.

In many lakes, the eutrophication level has reached the particularly favorable conditions for the existence of the pike perch population. For example, in Burtnieku Lake in the 1950's, water transparency was from $1.0 \mathrm{~m}$ to $1.5 \mathrm{~m}$, but nowadays it has been reduced to $0.4 \mathrm{~m}$. A similar situation exists in Lubāna Lake, where the level of water transparency is as low as in Burtnieku Lake. A favorable eutrophication level for pike perch in certain circumstances can also lead to disappearance of the population. For example, in Balvu Lake, in the winter of 1995/1996 the wide-scale dying off of pike perch as a result of oxygen deficiency took place. The pike perch population in this lake was renewed later through the introduction of their fingerlings.

The artificial propagation of catfish has also been commenced in Latvia. They have been released in separate bodies of water in the Gauja and Venta basins, as well as in at least 3 lakes, although the development of self-sustainable population in them has not yet been confirmed.

The catfish population associated with the Daugava has obviously also been increasing, as catfish are regularly caught in Ķīšezers, although captured rarely in previous years.

The distribution of asp in the last century was mainly connected with the Daugava, Gauja, Lielupe and the Venta, as well as the main tributaries of these rivers and lakes directly connected with them. Nowadays, there is no news about asp in angler's catches in the Bārta. An individual example has been caught in Liepāja and Pape lakes.

From the 1950s lakes inventory data, asp could be found in the three lakes directly connected with the Daugava. Nowadays it is found in 12 lakes, which is thought to be caused by the increase of the asp population in rivers and their more intensive migration to lakes.

In Latvia, the artificial propagation of vendace was commenced from at least 1900 . It took place regularly in the $1930 \mathrm{~s}$, and later till the $1980 \mathrm{~s}$, when vendace were released in at least 16 lakes $[1,8]$. They were released in more than 45 Latvian lakes overall. However, the total size of the vendace population in Latvia has tended to decrease, caused by unfavorable climate and anthropogenic factors, mainly eutrophication. It is quite probable that naturally regenerating populations in many lakes did not develop and consisted only of fish artificially released, and that they existed for only a short period.

Grayling, which can be encountered mainly in the Gauja and Venta basins' waterways [8,13], is now also released into the rivers of the Daugava and Lielupe basins, although the development of a naturally regenerating population is not yet known in these river basins.

The unplanned spread of various species of fish, as a result of artificial fish propagation, has also taken place. Thus, for example, in 2010, pike were released in some lake in the Rēzekne County, and bettering, which had not previously been found in Eastern Latvia, were also released together with the pike.
The transportation and release of many local species of fish is done regularly and in large numbers, as determined by the National programme for the reproduction of fish resources. These are mainly smolts or fingerlings of migratory fish of different ages. Bearing in mind that the distribution of migratory fish in Latvia is restricted by the number of accessible rivers, these releases do not change their distribution and occurrence in inland waters.

Up to the 1990s, a fisheries-type approach dominated in the research on fish in Latvia's inland waters. Research was done mainly on commercially significant fish species, i.e. the species of a greater commercial value or species which on balance dominated in fishing. Fish, mainly from commercial fishing catches, were analyzed in the research. Therefore, views differ substantially on the frequency of the occurrence of many species of fish at the beginning of the previous century and currently.

Thus, in the literature from the 1930s, ide was considered to be a fish which could be fairly regularly found. Chub, which was a similar species in appearance, was considered to be comparatively rare [7, 11]. From the 1950s lake inventory data, ide was found in $36 \%$ out of 549 lakes inspected, but chub - in only $9 \%$ [17]. However, in the last 20 years, in the inventory fishing, ide was found in 6\% out of 292 lakes inspected, but chub in $10 \%$ of lakes. The proportions of these species of fish in rivers are $3 \%$ and $42 \%$ respectively.

In the 1980s, a large population of ide had developed in Lubāna Lake after the artificial enlargement of their habitat. In the newly created lake - in the reservoir, the catch of ide reached $11.6 \mathrm{t}$ in 1987 , but was only $26 \mathrm{~kg}$ in 2010 . The second largest ide population was in Engures Lake, where the haul in 1969 was $10.9 \mathrm{t}$, but in 2010 it was only $10 \mathrm{~kg}$. This ide population was mainly created by the coastal semimigratory fish from the Gulf of Riga. The catches of ide in coastal waters fell from $28 \mathrm{t}$ in 1990 , to $0.1 \mathrm{t}$ in 2010 . The reduction in the ide population in Engures Lake is usually explained by the rather intensive fishing on the coastal waters in the Gulf of Riga. Whereas, the main reason in Lubāna Lake has obviously been the changes in its hydrological condition. In other Latvian water bodies, the reduction in ide numbers has obviously been caused by changes in environmental conditions.

The majority of species of fish which were not commercially used in large volumes in the first part of the previous century were considered to be rare [7]. They were not included in surveys and were not the objects of research. That is why there is practically no information about a whole range of species, about their distribution and occurrence, even relatively recently.

One such fish is bitterling, the occurrence of which is linked to the lower reaches of the Daugava, the Lielupe and Venta, with the lower reaches of the Daugava being assumed to be the northern boundary of the area of distribution [10]. Nowadays bitterling is found in 54 lakes and 55 rivers and the area of its distribution has reached the middle reaches of the Salaca in the Northern part of Latvia. Up until now, bitterling has not been found in the eastern part of Latvia. 
The situation is fairly similar with the sun bleak, with its area of distribution, as opposed to bitterling, covering all of Latvia's territory, but it was, however, considered to be a rarely found fish [7], as well as a common one [11]. Nowadays it is found in 229 lakes and 73 rivers.

Spined loach too was earlier considered to be a rarely found fish [7], but actually it is a very widespread species of fish which is often encountered. After 1990, spined loach has been found in 205 lakes and 112 rivers.

A new species in Latvia's inland waters is the northern golden loach Sabanejewia baltica, which was first found in 2008 in the Gauja and in the lower reaches of the Amata, but in 2009 in Kāša Lake. The occurrence of this species within Latvia is quite unclear. It was also found in the Venta River in the territory of Lithuania in 2002. The occurrence of the northern golden loach is not known in other areas bordering Latvia, like Belarus, Estonia and the Pskov region of Russia.

Bullhead and schneider were also considered to be rare fish species in the 1930s, but are quite frequently encountered nowadays. Thus, bullhead has been found in 152 rivers and 16 lakes, but schneider - in 74 rivers and one lake. Both fish species are more suited to river biotopes, which determine their rare occurrence in lakes.

In turn, Alpine sculpin, which was earlier ascribed to Latvia's coastal and inland waters [9, 13], obviously cannot be found. No specific incident is known about where it has been found in Latvia or in neighboring countries.

Some of the species have been relatively rare up until now, such as twaite shad and sabrefish. Neither of these species of fish is mentioned in the lists of fish bones found in archaeological excavations [12], nor in the $19^{\text {th }}$ century review about the economic importance of the Daugava [20].

They have not been caught during the research fishing in Latvia's inland waters, and only data about occasional catches in commercial fishing are available.

Twaite shad is mainly caught in coastal waters. It is found more to the south of Latvia, in the Baltic Sea. The catches of twaite shad in Lithuania in the first part of the previous century in the Curonian Lagoon was about 200 - 300 tonnes per year, while in Latvia the fishing has been occasional. In later years, the catch in Lithuania has rapidly declined, and in Latvia twaite shad has become rarer. From 1996, its numbers in the Curonian Lagoon again started increasing. Correspondingly, twaite shad has been caught more frequently in Latvian coastal waters. So, in the period from 1992-2002, only some examples were caught, but later it was regularly registered in coastal fishing, with its catches reaching up to 0.6 $\mathrm{t}$ in 2004. Allis shad, which is similar in appearance to twaite shad, which was earlier ascribed to Latvia's ichthyofauna [6, $11]$, is obviously found neither in Latvia's waters, nor in the Baltic Sea basin.

In the literature of the first half of the previous century, the catching of individual examples of sabrefish was noted in coastal lakes [19]. Since the end of the 1990s, it was regularly caught in Kī̄šezers. In fishing of eel in Jugla Lake in 2006, 70 examples of sabrefish were analyzed as by-catch. The number of sabrefish has rapidly increased in the Vistula Lagoon from the 1990 s.

It is thought that the increase in the number of sabrefish and twaite shad since the 1990s is caused by improvement in water quality of the lower reaches of the Nemuna and Vistula Rivers, where the spawning sites of these species are located. Their breeding in Latvia has not been confirmed until now, but they might be more frequently found in our waters now, as a result of climate change.

The occurrence of barbel Barbus barbus in Latvia's inland waters is doubtful. Initially though, barbel was reported to be seen in the Riga market - it was caught in a raid on the Liepāja port [4]. But a little later, news was received that one example of this species of fish was caught in the lower reaches of the Bārtas River, and since 1956 it has been included in the list of fish found in Latvia's freshwater (in the Bārtas River) [13]. Later the occurrence of barbel was also ascribed to the Daugava and Venta basins, even though no specific incidence of it having been caught has been mentioned. One individual from this fish species was also caught on the sea coast near Liepāja in 2006. Bearing in mind that barbel was not mentioned in fishing haul statistics from 1949 to 2010 for Liepāja Lake, into which the Bārtas River empties, the existence of a naturally regenerating population seems doubtful. It is thought that in the two previously mentioned examples barbel arrived to Latvia's coastal waters from the Curonian Bay in Lithuania, where this species of fish can be found in the rivers which empty into it.

Individual species of fish can nowadays be considered to have disappeared. Thus, for example, bones of blue bream were found during archaeological excavations at a settlement on the Lubāna lowlands (4 millennia BC) and near Dole Island on the Daugava (1 millennium BC) [12]. In the $19^{\text {th }}$ century blue bream, which had entered from the Gulf of Riga, was fished regularly in the Daugava [20]. In the last century however, blue bream had been ascribed to the Latgale lakes, as it was sold at the Daugavpils market [19]. It was rarely found in the Gulf of Riga or in freshwater. It could be encountered in the lower reaches of the Daugava and Gauja [11]. In fishing literature, blue bream is also ascribed to the waters of the Salaca and Venta basins. Whereas, in the research about the lakes in suburbs of Riga, blue bream is ascribed to Babīte Lake, Jugla Lake, Ķ̄išezers, Lielais Baltezers and Mazais Baltezers [8].

However, the only time when it was proved that a blue bream had been caught, was in the Plavinas Reservoir on the Daugava River in 1988 [16]. Blue bream might enter the Daugava, migrating from lakes in the Pskov region (in Russia), where it is found [18]. After 1988, no instance of a blue bream being caught is known in Latvia.

Archaeological excavations provide evidence that in the past (1st millennium BC to $13^{\text {th }}-14^{\text {th }}$ century) sturgeon was a fish that was found quite often in the Daugava [12]. All the authors, who wrote about Latvia's ichthyofauna in different periods, mention sturgeon, like the Atlantic sturgeon, in connection with Latvia's rivers [7, 8, 11, 13]. In recent years, however, the assumption has been made that the Atlantic 
sturgeon, which had disappeared from the Baltic Sea basin over 800 years ago, was later replaced by the American Atlantic sturgeon Acipenser oxyrinchus [3]. In such a case, one can assume that both species of sturgeon could once be found in Latvia's waters.

The introduction of various fish from the sturgeon family in Latvia's and other Baltic Sea nations' waters took place since $1885[8,20]$. Neither morphological nor genetic analyses have been done on the samples caught in Latvia's waters and, therefore, it cannot be proved whether they belong to the "local" sturgeon. News of the capture of various sturgeon-like species of fish in Latvia's waters was already published in the $19^{\text {th }}$ century, and it appeared in large numbers and more frequently in commercial fishing catches in the first years after their release.

The systematic belonging of some fish is being reviewed, influenced by the latest scientific findings. Where it is possible to establish morphological differences between sub-species or forms which were provided earlier, they are looked upon as new species with a species name.

Whitefish Coregonus lavaretus which can be found in the Baltic Sea basin, was allocated in the migratory form which spawns in rivers, and the form which spawns in the sea has now been offered the names Coregonus maraena and Coregonus widegren, respectively. Peipsi whitefish Coregonus maraenoides and Ludoga whitefish Coregonus lutokk [1], which were introduced into some Latvian rivers and lakes, are now also considered as new species. In a similar way, in the 1930's one species of whitefish Coregonus lavaretus, which was found in Latvia, was divided into three forms and can be recognized by their morphological signs [6]. However, systematic morphological or genetic analyses on the capture of a whitefish were not later done. Thus, currently it is not and will not be possible to determine which of the whitefish species have been found up till now in various water bodies in Latvia.

A similar case exists with another fish from the whitefish family - vendace. The ripus sub-species divided off earlier, the Coregonus albula ladogensis, is considered to be a separate species, Coregonus ladogae [26]. Ripus was introduced into a number of Latvian lakes [1]. However, the question about the overall status of this species and the existence of its population in Latvia's lakes is still debatable.

The research from 1949 published in the Russian language mentions that bullhead is represented in the Daugava by a subspecies - the Russian bullhead Cottus gobio koshewnikowi [14]. The main morphological sign for distinguishing the Russian bullhead from the common bullhead is an incomplete lateral line. At the same time, it is noted that this difference cannot be observed in all individual fish [14]. In another research, it has been established that an incomplete lateral line can only be observed in young bullhead individuals, but that in adult fish it is the same as the common bullhead. Nowadays, there is a suggestion that the Russian bullhead should be recognized as a separate species Cottus koshewnikowi, naming it the Volga bullhead [3].
It should be noted that a real difference of opinions can be observed in systematic ichthyological research in relation to the Cottidae. The view [5] is that only three species of bullhead can be found in Europe. At the same time, other authors [3] distinguish eight new species of bullhead. Neither the Alpine sculpin, nor the common bullhead is on the distribution maps for this family of fish in Latvia included in this work. However, the Volga bullhead's area is marked from the Daugava northwards. At this moment, at least 100 common bullhead locations are known in the territory of Latvia to the south of the Daugava and in 152 rivers throughout the country. This species can also be found in all countries neighbouring Latvia.

Russian (Volga) bullhead's systematic status is obviously a topic for discussion, as the works of some authors mention it as a species [3], a sub-species [14], or a haplotype [5].

\section{IV.CONCLUSIONS}

1. When comparing archaeological excavation data with the $19^{\text {th }}-20^{\text {th }}$ century publications, statistical data from fishing and the results of field research, it can be concluded that the distribution and occurrence of individual species of fish has been altered under the influence of climate change. The distribution of warmwater species, such as catfish, pike perch and asp, has increased, but that of coldwater species, like vendace and lake smelt, has decreased.

2. In temperate zone conditions, a significant factor forming the structure of the fish community in lakes is the wide-scale winterkills of fish due to conditions of oxygen deficiency. Anthropogenic factors also influence this phenomenon, as the intensive suffocation of fish is more pronounced in eutrophic and polluted waters.

3. Anthropogenic activity, like the building of barriers on rivers, the hydromorphological transformation of rivers, pollution and eutrophication, has influenced the occurrence and distribution of fish much more significantly than natural factors.

4. As a result of human activity, new species of fish have been acclimatized in Latvia's ichthyofauna. Two of them, the Prussian carp and Amur sleeper, have adapted and are creating self-regenerating populations. Such fish species as catfish, pike perch, grayling and eel have been artificially spread in Latvia's inland waters by transporting and artificially propagating them.

5. The occurrence of some species of fish in Latvia's waters, which in the $20^{\text {th }}$ century were considered to be rare, like sabrefish and twaite shad, is increasing, which could possibly be caused by an increase in the number of individuals in the populations in the Baltic Sea's lagoons, in the Curonian and the Vistula lagoons.

6. The blue bream and the Atlantic sturgeon, and from the latest research, even the American Atlantic sturgeon, have obviously disappeared in Latvia.

7. From 2007, a new fish species, the Northern golden loach was registered in Latvia's fauna. Its location in the Gauja basin currently is the furthest known location of this species to the north. 
8. The latest data gained in fishing research shows that the species of fish, which were considered to be fairly rare in the first half of the $20^{\text {th }}$ century in Latvia, can be frequently encountered nowadays. The reason for this difference might be the lack of relevant research.

9. As a result of changes made in fish classification, in the coming years some new fish species could be added to Latvia's ichthyofauna.

\section{REFERENCES}

1. Andrušaitis, G. Zivju savairošana un aklimatizācija Latvijā [Breeding and acclimatization of fishes in Latvia]. Grām.: Latvijas PSR iekšējo ùdeņu zivsaimniecība IV. Rīga, 1960., 41.-70. lpp.

2. Kawall, H. Fische in Kurland und an den Küsten der dasselbe begränzenden Ostsee, mit Berücksichtigung von Livland. Das Inland. 23. Jahrg., 1858, Nr. 33, 534-536 S., Nr. 35, 561-598 S., Nr 36, 579-583 $\mathrm{S}$.

3. Kottelat, M. and Freyhof, J. Handbook of European freshwater fishes. Berlin, 2007, 646 pp.

4. Krēmanis, A. Jauna zivs mūsu ūdenos [New fish species in our waters] Zvejniecības mēnešraksts, 1937., Nr. 9., 278.-279. lpp.

5. Maitland, P. S. Guide to freshwater fish of Britain and Europe. Hamlyn, London, 2000, 256 pp.

6. Mannsfeld, W. Studien an Coregonen des Ostbaltikums. Archiv Fur Hydrobiologi, 1930, Band XXI, Heft 1, 65-94. S.

7. Mansfelds, V. Latvijas zivis [Fishes of Latvia]. Grām.: Latvijas zeme, daba un tauta. II. Rīga, 1936., 490.-519. lpp.

8. Plikšs, M., Aleksejevs, Ē. Zivis [Fishes]. Rīga, 1998., 304. lpp.

9. Priedītis, A. Zivkopība [Fish farming]. Rīga, 1947., 422. lpp.

10. Schneider, G. Die Süsswasserfische des Ostbaltikums und ihre Verbreitung innerhalb des Gebietes. Archiv für Hydrobiologie, 1925, Bd. 16, 133-155 S.

11. Silinšs, J. Latvijas zivis [Fishes of Latvia]. Jaunais zinātnieks, 1936., Nr. 37., $87 \mathrm{lpp}$.

12. Sloka, J. Akmens laikmeta lomi. Grām.: Dabas un vēstures kalendārs 1989. gadam. Rīga, 1988., 35. lpp.

13. Sloka, J. Apalmutes - Cyclostomata. [Jawless fishes- Cyclostomata]. Zivis - Pisces [Fishes- Pisces]. Grām.: Latvijas dzīvnieku pasaule. Rìga, 1974., 87.-101. lpp.

14. Берг, Л. С. Рыбы пресных вод СССР и сопредельных стран [Freshwater fishes of USSR and thouse neighbouring countries]. Часть. 3., М. - Л, 1949., с. 929-1382.

15. Богуцкая, Н. Г., Насека, А. М. Каталог бесчелюстных и рыб пресных и солоноватых вод России с номенклатурными и таксономическими комментариями [Catalogue of freshwatwer and brackhishwater lampreys and fishes of Russia with commentaries on nomenclature and taxsonomy]. Москва, 2004, 389 c.
16. Дирипаско, О. А. О поимке синца Abramis ballerus в Плявиньском водохранилище (Бассейн Даугавы) [Capture of blue bream Abramis ballerus in the reservoir Plavinas (the river Daugava)]. Bonpocbl ихтиологии, 1988, т. 28, вып. 4., с.688-689.

17. Котов, Н. Д., Никанорова, Е. А., Никаноров, Ю. И. Рыбохозяйственные исследования озер Латвийской CCP [Lakes fishery reserch of the Latvian SSR]. Рыббое хозяйство внутренних водоемов Латвийской ССР. Вып. 2. Рига, 1958, с. 259-292.

18. Лесненко, В.К. Псковские озера [The lakes of Pskov]. Л., 1988, 112 c.

19. Николаев, И. И. Видовой состав рыб Латвийской ССР [The species composition of fishes of Latvia SSR]. Труды Латвийского отделения ВНИРО. Вып. 1. Рига, 1953, с. 5-27.

20. Сапунов, А. Река Западная Двина [The river Daugava]. Витебск, $1893,512$.

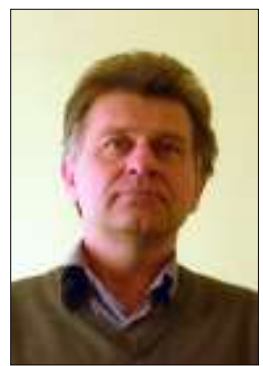

Eriks Aleksejevs researcher of Inland waters laboratory, Fish Resources Research Department, Institute of Food safety, animal health and environment BIOR since 2010. Eriks Aleksejevs has been staff of institutes and agencies of Fisheries research (BaltNIIRH (1985- 1990), LATFRI (19912004) and LATFRA (2004- 2009)). The main research is lake fishes and fisheries. He has participated as a lake fish expert in 6 different local projects as well as is author of 7 publications. He has a biologist diploma (1985) Address: Lejupes 3, LV- 1076, Riga, Latvia

Phone: +37167612536

E-mail: eriks.aleksejevs@bior.gov.1v

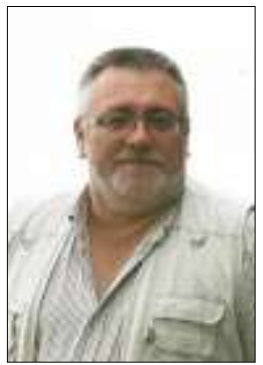

Janis Birzaks, head of Inland waters laboratory, Fish Resources Research Department, Institute of Food safety, animal health and environment "BIOR" since 2010. Janis Birzaks has been staff of institutes and agencies of Fisheries research (BaltNIIRH (1986- 1990), LATFRI (1991- 2004) and LATFRA (2005-2009)). The main research is river fishes ecology with special interest of migratory species. He has involved in International Council for the Exploration of the Sea (ICES) since 1995 as member of working groups of Baltic salmon (WGBAST) and eel (WGEEL), as well as member of ICES Advisory committee (ACOM). Janis Birzaks is author of about 30 publications

He has a biologist diploma (1987).

Address: Lejupes 3, LV- 1076, Riga, Latvia

Phone: +37167612536

E-mail: janis.birzaks@bior.gov.lv

\section{Ēriks Aleksejevs, Jānis Birzaks. Ilglaicīgās izmainas Latvijas iekšējo ūdenu ihtiofaunā}

Rakstā analizēta un salīdzināta informācija par zivju izplatību un sastopamību no zinātniskām publikācijām, dienesta atskaitēm, "BIOR" datubāzēm par zvejas statistiku un zivju mākslīgo pavairošanu, kā arī lauka pētijumos, kas veikti no 1990. gada līdz 2010. gadam par 1097 ezeriem, 435 upēm un 227 mākslīgām ūdenskrātuvēm.

Salīdzinot arheoloǵisko izrakumu datus ar 19.- 20.gs zinātniskajām publikācijām un lauka pētījumu datiem pēc 1990.g. iespējams konstatêt, ka dažu zivju sugu izplatīiba un sastopamība dažādos periodos ir mainījusies, kas acīmredzot saistītas ar klimata mainu. Dažu eiritermo zivju sugu, piemēram, zandarta, sama un salates izplatība Latvijas iekšējos ūdeņos senāk bijusi daudz plašāka kā 19. un 20. gadsimtā, taču pašlaik tā atkal palielinās. Savukārt stenotermo zivju sugu repša un ezera salakas populāciju skaits Latvijas ezeros ir samazinājies laikā no 1950. gadiem.

Būtiskāk ihtiofaunu ir ietekmējusi antropogēnā darbība 20 gadsimtā. Tās ietekmi nepārprotami iespējams konstatēt uz celotājzivīm un to izplatību Latvijas upēs. Daugavas HES kaskādes celtniecība būtiski samazināja diadromo zivju sugu izplatību Latvijā. Mazajās un vidēja lieluma upēs ir vairāk kā 700 antropogēni šḳēeṣ̌li.

Dažu tipu ezeros ichthyofaunas struktūru formējošs faktors ilgtermiṇā ir zivju bojā eja skābekḷa dfeficīta rezultātā.

Sugu izplatību un sastopamību ietekmējuši arī tādi faktori kā ūdenstilpju hidromorfologiskā pārveidošana un ūdens kvalitātes pasliktināšanās.

Latvijas iekšējos ūdenos laikā no 19. gadsimta beigām veikti 23 zivju sugu aklimatizācijas mēgeinājumi. Pašatražojošās populācijas izveidojušas sudrabkarūsa Carassius gibelio un rotans Percottus glenii. Mākslīgi izplatītas tādas zivju sugas, kā plaudis, zandarts, zutis, sams un alata.

Palede Alosa fallax un kaze Pelecus cultratus 20. gadsimta sākumā uzskatîtas par retām. No 1990. gadiem to daudzumam Latvijas piekrastes un iekšējos ūdennos ir tendence pieaugt. Jūras nēgis Petromyzon marinus uzskatāms par sugu, kas ieklīst Latvijas ūdeņos.

No 2008. gada Latvijā konstatēta jauna zivju suga Ziemeḷu zeltainais akmeņgrauzis Sabanejewia baltica, tā atradne Gaujas upē pašlaik ir tālākā zināmā ziemeḷu virzienā.

Jaunāko pētījumu par zivju izplatību rezultāti ḷauj mainīt priekšstatus par tādu zivju sugu kā sapals, spidiḷıis, ausleja, platgalve un pavīke statusu Latvijas iekšējos ūdeņos. Vēl 20. gadsimta 30. gados tās uzskatītas par relatīvi reti sastopamām sugām, to noteicis pētījumu trūkums, nevis reālā situācija dabā. 
Spare Abramis ballerus un Atlantijas store Acipenser sturio, bet pēc jaunākajiem zinātniskajiem datiem arī Amerikas Atlantijas store Acipenser oxyrinchus, Latvijā acīmredzot ir izzudušas.

Saskaņā ar izmaiņām zivju nomenklatūrā nākotnē Latvijas ichthyofaunai varētu tikt pievienotas vairākas jaunas zivju sugas.

Эрик Алексеев, Янис Бирзакс. Долгосрочные изменения ихтиофауны внутренних вод Латвии

В статье проводится анализ и сравнение распространения и встречаемости видов рыб на основе данных из научных статей, служебных отчетов, баз данных института БИОР о промысловом рыболовстве и зарыблении, а также данные полевых работ с 1990 по 2010 годы, в целом о 1097 озерах, 435 реках и 227 водохранилищах. Сравнивая данные археологических раскопок с результатами публикаций 19-20 веков и полевых исследований, можно заключить, что долгосрочные изменения в распространении рыб во внутренных водах Латвии были связаны с изменчивостью климата. Распространение эвритермных видов, таких как: сом, судак и жерех, ранее было значительно шире, чем в XIX и XX столетиях. В наши дни ареал этих видов вновь расширяется. В свою очередь, число популяция стэнотермных видов ряпушки и озерной корюшки сокращается после 1950-х годов. Влияние антропогенных факторов увеличилось с ХХ века. Это особенно четко проявляется в распространении мигрирующих рыб. Так, строительство каскада ГЭС на реке Даугава существенно уменьшило распространение диадромных видов рыб. В реках среднего размера и малых реках число плотин превышает 700. Существенным фактором формирования видового состава сообществ рыб являются заморы рыб, происходящие под воздействием как природных, так и антропогенных факторов. Существенно на распространение и встречаемость видов рыб повлияло гидроморфологическое преобразование рек и ухудшение качества природных вод.

C конца XIX века в водоемах на территории Латви было сделаны попытки аклиматизаци порядка 23 выдов рыб. Самовоспроизводящиеся популяции образовали серебряный карась Carassius gibelio и ротан Percottus glenii. Искусственно были распространены такие виды, как лещ, судак, сом, угорь и хариус.

Встречаемость финты и чехони, считавшимися редкими в водах Латвии с начала ХХ века, особенно увеличилась, в прибрежных водах. Морская минога является видом, случайно посещающим реки Латвии. В 2008 году в реке Гауя был обнаружен новый выд рыб для Латвии - балтийская щиповка Sabanejewia baltica.

Результаты исследований последнего времени позволяют пересмотреть предыдущие представления о распространении и встречаемости таких видов рыб, как голавль, горчак, верховка, бычок-подкаменщик и быстрянка. Ещё в 20- 30-х годах эти виды рыб рассматривались как относительно редкие, однако, это было обусловлено отсутствием исследований, а не реальным положением в природе. Синца и Атлантического осетра, по новейшим представлениям также Американского Атлантического осетра, надо считать исчезнувшими видами во внутренних водах Латвии. 